\title{
Variation in biological and physicochemical parameters of the soil affected by uncontrolled landfill sites
}

\author{
Barbara Breza-Boruta $^{1} \cdot$ Joanna Lemanowicz $^{2} \cdot$ Agata Bartkowiak $^{3}$
}

Received: 30 December 2014/ Accepted: 27 August 2015/Published online: 25 January 2016

(C) The Author(s) 2015. This article is published with open access at Springerlink.com

\begin{abstract}
Defining the biological and physicochemical parameters in soil under illegally dumping sites provides information on the real threat and the direction of changes in the soil environment. The aim of the study was to investigate the effect of uncontrolled dump sites which differed in the composition of the waste deposited on the development of selected groups of soil microorganisms and the activity of redox enzymes and selected physicochemical soil parameters. Additionally, it was verified whether the biological and physicochemical parameters differ in soil depending on the depth $(0-20$ and $20-40 \mathrm{~cm})$. The research covered three waste landfill sites (W1, W2, W3), the arable field (A) found in the zone of the effect of the dumping site as well as the control point (C). The microbiological analyses show that most amylolytic microorganisms $\left(87.0 \times 10^{5} \mathrm{cfu}\right)$, celullolytic $\left(46.4 \times 10^{5} \mathrm{cfu}\right)$, proteolytic $\left(148.6 \times 10^{5} \mathrm{cfu}\right)$ and bacteria in total
\end{abstract}

Barbara Breza-Boruta

breza@utp.edu.pl

Joanna Lemanowicz

j109@interia.pl

Agata Bartkowiak

bartkowiak@utp.edu.pl

1 Department of Microbiology and Food Technology, Faculty of Agriculture and Biotechnology, University of Technology and Life Sciences, Bernardyńska 6 St, 85-029 Bydgoszcz, Poland

2 Sub-Department of Biochemistry, Faculty of Agriculture and Biotechnology, University of Technology and Life Sciences, Bernardyńska 6 St, 85-029 Bydgoszcz, Poland

3 Department of Soil Science and Soil Protection, Faculty of Agriculture and Biotechnology, University of Technology and Life Sciences, Bernardyńska 6 St, 85-029 Bydgoszcz, Poland $\left(123.2 \times 10^{5} \mathrm{cfu}\right)$ were isolated from the surface later of control soil (C), and definitely least—from the area of dumping sites W1 and W2. The waste accumulated in W1 and W2 led to the soil depletion in organic matter, inhibited the development of microorganisms and their enzymatic activity. The soil under landfill site W3 showed the highest values recorded for physicochemical properties, the count of Actinobacteria, as well as the activity of dehydrogenases and catalase. The concentration of heavy metals in soil under landfill site W3 was even tenfold higher than the values recorded at the other measurement points, which must have been due to the effect of the type of the waste dumped in landfill site W3, where biodegradable waste of organic origin dominated. Disturbing the biological control and unfavourable changes in the microbiocenotic composition were mostly revealed in soil at landfill site W1.

Keywords Catalase - Dehydrogenases - Heavy metals . Landfill $\cdot$ Microorganisms $\cdot$ Soil

\section{Introduction}

Uncontrolled waste landfill sites pose a serious threat to the operation of the natural environment as well as to human and animal health. Unlike the controlled domestic waste landfill sites, they are not in any way secured from the soil with a layer of geomembrane; neither do they have hydroisolating insulation nor a separated protection zone (Guan et al. 2014). Of all different types of the mixed waste deposited, hazardous waste is also found in, e.g. paint, varnish, electrolyte residue, used batteries and fluorescent tubes, expired medications, plant protection agents or their packaging. As a result of the rainwater infiltration, there is reported leaching of chemical compounds polluting the soil 
as well as surface and ground waters. The migration of toxic substances from the waste deposited and their leachates down the soil profile poses a risk of an increasing degradation of the environment, especially the soil environment. The recognition of the impact of uncontrolled landfill sites on the biological and physicochemical state of soils is essential from the point of view of environmental protection and human ecology (Fraczek and Ropek 2011; Nagarajan et al. 2012).

The biochemical soil properties reflect the effect of favourable and unfavourable environmental factors. The quantitative changes in microorganisms and, consequently also a change in the enzymatic activity of soils, are the earliest signals of changing life processes in the environment (Bielińska et al. 2013). Microorganisms are an integral soil component and play a number of functions in the processes which are key to the energy flow and the circulation of matter in the environment (transformations of organic matter, making nutrients available, biodegradation of pollutants, creating and maintaining the adequate soil structure). As a result of the supply of new resources of matter, the intensity of biochemical processes can drop rapidly or-just the opposite-increase. Organic components show a varied susceptibility to biodegradation since the waste of plant and animal origin (the so-called waste getting rotten), as well as paper undergo degradation easily (Sinegani et al. 2005; Halasz et al. 2008; Salazar et al. 2011). Inorganic fractions (e.g. metals, glass, ceramics, ash, debris), although not undergoing biodegradation, affect its pattern. Many chemical compounds can be toxic or mutagenic, which affect the metabolism of soil organisms and their release of the products of metabolism. Various metals, e.g. $\mathrm{Ni}, \mathrm{Cd}, \mathrm{Pb}, \mathrm{Cr}, \mathrm{Zn}$, detergents, plant protection agents, cyanides or ammonia, have an unfavourable effect on the development of some microorganisms. They inhibit the metabolism of anaerobic microorganisms which are more sensitive than the aerobic ones (Frey et al. 2006).

Soil pollution with heavy metals slows down the biological processes as a result of a change in the species abundance and diversity of soil macro- and microorganisms. The chemical soil degradation occurs fast, and under such conditions microorganisms can have a limited or even complete lack of access to nutrient and energy substrates which, as a result, leads to weakening the circulation of some biogenes. The literature which covers the effect of heavy metals on microorganisms, although vast (Frey et al. 2006; Oliveira and Pampulha 2006), is not however, unambiguous. Frey et al. (2006) and Khan et al. (2010) point to a negative effect of heavy metals on microorganisms, whereas Dong et al. (2006) demonstrated that some stimulate the multiplication of various bacterial species. An important role in stimulating or inhibiting the effect of heavy metals on microorganisms and their enzymatic activity is attributed to physicochemical soil parameters: $\mathrm{pH}$, richness in nutrients, grain size composition, soil type. In the soil environment some metals, e.g. nickel, especially in neutral soils, undergo biological, chemical and physicochemical sorption, which weakens its effect on microorganisms and, at the same time, it can activate some enzymes (Schloter et al. 2003; Oliveira and Pampulha 2006).

The role played by microorganisms in soil makes the parameters based on microbiological studies supply information which cannot be achieved by applying physical and chemical measurements. Microorganisms react fast to changes in the environment and so they get easily adapted to new conditions and quickly respond to environmental stresses (Romaní et al. 2006). They constitute the main source of many soil enzymes; the greatest role of which is played by enzymes-representing classes' oxidoreductases and hydrolases. Their activity shows the degree and the level of changes in the soil environment affected by natural and anthropogenic factors. Dehydrogenases [EC1.1.1] serve as an indicator of the total metabolic activity of microbiological soil population catalysing the redox reaction (Salazar et al. 2011). Soil catalase [EC 1.11.1.6] catalyses the decomposition of harmful hydrogen peroxide to water and molecular oxygen. It is present in the cells of all the microorganisms which use oxygen for breathing processes. Microorganisms in the soil are responsible for the degradation of organic matter to release nutrients (Nwaogu et al. 2014). When heavy metals are retained in the soil through repeated contamination, they interfere with microbial key biochemical processes, impair enzyme synthesis and activity in soil. Excessive concentration of heavy metals in plants can cause, e.g. oxidative stress.

Microbiological and biochemical indicators are considered most dynamic and sensitive, and changes in the life functions of soil microorganisms are often considered an early signal of a decrease or increase in the soil quality. The evaluation of the soil processes based on the microbiological parameters concerns investigating the size and the diversity of the population of soil microorganisms (functional, taxonomic), as well as biochemical functions. The literature review (Schloter et al. 2003; Bielińska and Mocek-Płóciniak 2009) shows that microbiological and enzymatic parameters are among most frequently selected for soil state monitoring.

The aim of the research has been to evaluate the effect of uncontrolled landfill sites which differed in the composition of deposited waste on the development of selected groups of soil microorganisms and the activity of redox enzymes against selected physicochemical soil parameters. 


\section{Materials and methods}

\section{Location of soil sampling}

Having made the site visit in the autumn of 2013 for the purpose of research, there three locations of illegal waste landfill sites in the forest area in the Bydgoszcz commune were selected $\left(53^{\circ} 12^{\prime} \mathrm{N} ; 18^{\circ} 01^{\prime} \mathrm{E}\right.$; the Kujawy and Pomorze Province, central Poland, Europe). Those were point landfill sites which covered the areas of about $25 \mathrm{~m}^{2}$, labelled W1, W2, W3. In the morphological composition of object W1, mixed waste, including debris and ceramic waste, glass, plastics, metals, textiles and used electrotechnical equipment were present. In object W2, electrotechnical equipment, tyres and textiles were present, whereas, landfill site W3 accumulated the waste of organic origin from households and cut grass as well as residue from garden maintenance. $30 \mathrm{~m}$ away from landfill site $\mathrm{W} 3$ in the arable field of corn, Clarica cultivar (FAO 220), in monoculture (to be used for silage) another sampling point was defined labelled (A), to determine the zone of the effect of landfill site W3 on arable soil. As control point (C) a location far from the waste landfill sites was defined and not within the zone of their effect. Soil samples were taken with the Egner stick from two depths 0-20 and $20-40 \mathrm{~cm}$. In the landfill site, a layer of waste was uncovered and then soil was sampled. Bulk soil samples were collected for each studied site W1, W2, W3, A and the control. Each soil sample was a mixture of five subsamples taken randomly in the selected area of $5 \times 5 \mathrm{~m}$. The soil samples, transported to the laboratory in sterile plastic bags were stored at $4{ }^{\circ} \mathrm{C}$ for microbial and enzyme analysis and room temperature to physicochemical determinations.

\section{Soil analysis}

\section{Physicochemical parameters of the soil}

In the air-dried soil samples with disturbed structure, sieved through $\varnothing 2 \mathrm{~mm}$ screen, selected physicochemical properties were assayed: $\mathrm{pH}$ in $\mathrm{H}_{2} \mathrm{O}$ and $\mathrm{pH}$ in $\mathrm{KCl}$ measured potentiometrically (PN-ISO 10390: 1997), organic carbon $\left(\mathrm{C}_{\text {org }}\right)$ with the Tiurin method (PN-ISO14235: 2003), the granulometric composition with the laser diffraction method applying the Masterssizer MS 2000 analyser. In the samples analysed,the total content of lead, nickel and cadmium was measured after the mineralisation in the mixture of $\mathrm{HF}+\mathrm{HClO}_{4}$ acids with the Crock and Severson's method (1980). The total contents and mobile forms were determined by applying the method of atomic absorption spectroscopy with the PU 9100X spectrometer (Philips).
Microbial analyses

The microbiological analyses of the soil samples collected involved determining the total count of heterotrophic bacteria, actinomycetes, filamentous fungi and amylolytic, cellulolytic, proteolytic microorganisms. Ten grams of each soil sample was added to $90 \mathrm{ml}$ of Ringer's solution. After homogenisation for $30 \mathrm{~min}$, tenfold serial dilutions were made $\left(10^{-1}-10^{-6}\right)$. Then inoculations of the soil solutions prepared were made on proper culture media. To determine the total count of bacteria, Standard I nutrient agar (provided by Merck) was used (Atlas 1997). Actinomycetes were isolated on the Pochon medium with 100 nystatin $\mu \mathrm{g} \mathrm{ml}^{-1}$ (Pochon and Tardieux 1962) and filamentous fungi were isolated on the Martin medium (1950). The number of amylolytic microorganisms was determined on the selective medium with $0.2 \%$ of starch (Difco) according to Boguszewska (1980). Cellulolytic microorganisms were tested on the agar medium containing $0.1 \%$ sodium carboxymethylcellulose (Sigma) according to the method Strzelczyk and Szpotański (1989). Proteolytic microorganisms were isolated on the medium with $2 \%$ gelatine (Difco) according to Pochon and Tardieux (1962).

The incubation of microorganisms was carried out at $25{ }^{\circ} \mathrm{C}$ for $4-5$ days, and 10 days-for actinomycetes. All determinations were performed in four replicates. After the incubation period, the colonies grown on Petri dishes were counted. The number of colony forming units (CFU) was determined per $1 \mathrm{~g}$ of soil dry matter (CFU g ${ }^{-1}$ d.m. of soil).

\section{Biochemical measurements}

Soil moist samples were sieved ( $2 \mathrm{~mm}$ mesh) and stored in a plastic box at $4{ }^{\circ} \mathrm{C}$ for not less than 2 days in order to stabilise the microbial activity and analysed for catalase and dehydrogenases activities within 1 week. The activity of selected redox and hydrolytic enzymes: the activity of dehydrogenases (DEH) [E.C. 1.1.1] in soil with the Thalmann method (1968), after soil incubation with 2,3,5triphenyl-tetrazolium chloride and a measurement of triphenylformazan (TPF) absorbance at $546 \mathrm{~nm}$ and was expressed as mg of TPF $\mathrm{kg}^{-1} 24 \mathrm{~h}^{-1}$. The activity of catalase (CAT) [E.C. 1.11.1.6] was recorded in soil with the Johnson and Temple method (1964) and measured by applying the manganometric titration of the surplus of $\mathrm{H}_{2} \mathrm{O}_{2}$ under acidic conditions.

\section{Statistical analysis}

For the population of the results reported, the measures of variation were calculated (standard deviation-SD, coefficient of variation-CV \%). The coefficient of variation of the parameters analysed was calculated as follows: 
$\mathrm{CV}=(\mathrm{SD} / \mathrm{X}) \times 100$, where: $\mathrm{CV}$-coefficient of variation (\%), SD-standard deviation, $\mathrm{X}$-arithmetic mean. The values where $0-15,16-35$, and $>36 \%$ indicate low, moderate, or high variability, respectively. The results of research were statistically verified applying a two-factor analysis of variance (ANOVA), assuming factor I-the sampling location and factor II-the depth. Significant statistical differences of all the variables among the different sites studied were established using Tukey's test at $p=0.05$. At the same time the results of the analyses of the properties investigated were exposed to the analysis of simple correlation $(p<0.05)$ to define the level of dependence between the respective properties. The analysis of correlation was performed in the STATISTICA for WINDOWS $P l$ software.

\section{Results and discussion}

The basic physicochemical properties of the soil samples are broken down in Table 1. The breakdown reveals that the soils studied showed the reaction from acid to neutral; the values expressed in $\mathrm{pH}_{2} \mathrm{O}$ ranged from 4.42 to 7.35 , while in $1 \mathrm{M} \mathrm{KCl}$-from 3.36 to 7.30 (Table 1). The highest $\mathrm{pH}$ value was recorded in the soil under landfill site W3 and the lowest value-under W2. In the surface horizons sampled from the landfill sites both the active acidity and exchangeable acidity were lower than in the sub surface horizons. Mostly supplied with debris, various forms of calcium result in a decrease in the acidity of the surface soil layer they were stored on, which was not noted in the samples under landfill site W1. Such materials do not cover the soil in specific objects evenly, and so in sandy soils, accompanied by a strong water permeability, within the landfill site a decrease in the acidity is often point-like in nature (Bielińska and Mocek-Płóciniak 2009). All the illegal landfill sites (W1, W2, and W3) were located in the forest soil area, similarly as the control point. Acid soils are common in forest ecosystems, and there is documented evidence of $\mathrm{pH}$ influencing transformations of organic matter in soil (Tonon et al. 2010). It was found that a definitely higher $\mathrm{pH}$ value in soil under landfill $\mathrm{W} 3$, as compared with the control $\left(\mathrm{pH} \mathrm{H}_{2} \mathrm{O} 4.74\right)$, which could have been due to the organic origin waste decomposing there. According to Wang et al. (2013), the kind of the matter accumulated and the processes of its decomposition can contribute to the change in the soil reaction. One can thus assume that the waste in landfill site W3 could have changed its reaction from acid to neutral.

The dominant fraction in the soil samples studied was the sand fraction from 2.0 to $0.05 \mathrm{~mm}$ in diameter. The analysis of the grain size composition noted inconsiderable amounts of the clay fraction from 0.68 to $2.21 \%$. The samples were classified only as two grain size groups: loose sand and loam sand (according to USDA).

The content of organic carbon in soil fell within a wide range: $1.61-26.56 \mathrm{~g} \mathrm{~kg}^{-1}$ (depending on the object and the soil sampling depth) (Table 2), which was confirmed with a high coefficient of variation CV $83.03 \%$ (Table 5). Based on the analysis of variance there was a significant effect of the soil sampling location and depth (Table 2). The highest amounts were reported in the surface horizons of all the objects (mean $14.0 \mathrm{~g} \mathrm{~kg}^{-1}$ ). The maximum amount of the parameter was noted in the surface horizon under landfill site W3 (26.56 $\mathrm{g} \mathrm{kg}^{-1}$ ), which included most organic waste. Similar relationships were reported in uncontrolled landfill sites by Meller et al. (2012). The values of organic carbon in the $0-20 \mathrm{~cm}$ horizon of landfill site W3 were higher than the values in the arable field $\left(10.48 \mathrm{~g} \mathrm{~kg}^{-1}\right)$. The lowest amount of $\mathrm{C}_{\text {org }}$ was assayed in soil under $\mathrm{W} 1$ and $\mathrm{W} 2$ (in the surface layer 4.11 and $5.52 \mathrm{~g} \mathrm{~kg}^{-1}$, respectively). The comparison of those values with the control $\left(23.35 \mathrm{~g} \mathrm{~kg}^{-1}\right)$ demonstrated soil organic matter depletion under $\mathrm{W} 1$ and W2. Forest soils
Table 1 Selected physicochemical properties

\begin{tabular}{|c|c|c|c|c|c|c|}
\hline \multirow[t]{2}{*}{ Sampling location } & \multirow{2}{*}{$\begin{array}{l}\text { Horizon } \\
\mathrm{cm}\end{array}$} & \multicolumn{2}{|l|}{$\mathrm{pH}$} & \multicolumn{3}{|l|}{ Fractions (\%) } \\
\hline & & $\mathrm{H}_{2} \mathrm{O}$ & $\mathrm{KCl}$ & $2.0-0.05 \mathrm{~mm}$ & $0.05-0.002 \mathrm{~mm}$ & $<0.002 \mathrm{~mm}$ \\
\hline \multirow[t]{2}{*}{$\mathrm{C}$} & $0-20$ & 4.74 & 3.36 & 79.77 & 19.5 & 1.08 \\
\hline & $20-40$ & 4.46 & 3.83 & 87.28 & 12.8 & 0.68 \\
\hline \multirow[t]{2}{*}{ W1 } & $0-20$ & 4.74 & 4.55 & 85.47 & 12.82 & 1.71 \\
\hline & $20-40$ & 4.83 & 4.67 & 92.59 & 6.47 & 0.94 \\
\hline \multirow[t]{2}{*}{ W 2} & $0-20$ & 4.42 & 4.35 & 77.05 & 20.73 & 2.21 \\
\hline & $20-40$ & 4.52 & 4.49 & 85.60 & 12.48 & 1.91 \\
\hline \multirow[t]{2}{*}{ W3 } & $0-20$ & 7.17 & 6.87 & 77.33 & 21.68 & 1.00 \\
\hline & $20-40$ & 7.35 & 7.30 & 79.98 & 18.05 & 1.97 \\
\hline \multirow[t]{2}{*}{ A } & $0-20$ & 6.09 & 5.37 & 76.39 & 21.67 & 1.94 \\
\hline & $20-40$ & 6.18 & 5.93 & 76.66 & 21.30 & 2.04 \\
\hline
\end{tabular}

$C$ control, $W 1, W 2, W 3$ uncontrolled landfill sites, $A$ arable field 
Table 2 Content of organic carbon and selected heavy metals

\begin{tabular}{|c|c|c|c|c|c|c|c|c|c|c|c|c|}
\hline \multirow{4}{*}{$\begin{array}{l}\text { Sampling location } \\
\text { I factor }\end{array}$} & \multirow{2}{*}{\multicolumn{3}{|c|}{$\frac{\mathrm{C}_{\text {org }}}{\mathrm{g} \mathrm{kg}^{-1}}$}} & \multicolumn{3}{|l|}{$\mathrm{Pb}$} & \multicolumn{3}{|l|}{$\mathrm{Ni}$} & \multicolumn{3}{|l|}{$\mathrm{Cd}$} \\
\hline & & & & \multicolumn{9}{|c|}{$\mathrm{mg} \mathrm{kg}^{-1}$} \\
\hline & \multicolumn{12}{|c|}{ Depth $(\mathrm{cm})$ II factor } \\
\hline & $0-20$ & $20-40$ & mean & $0-20$ & $20-40$ & mean & $0-20$ & $20-40$ & mean & $0-20$ & $20-40$ & mean \\
\hline $\mathrm{C}$ & 23.35 & 12.06 & 17.70 & 7.326 & 4.938 & 6.132 & 3.788 & 3.575 & 3.681 & 0.325 & 0.413 & 0.369 \\
\hline W1 & 4.11 & 2.37 & 3.24 & 3.714 & 0.336 & 2.025 & 4.000 & 4.063 & 4.031 & 0.400 & 0.425 & 0.413 \\
\hline W2 & 5.52 & 1.61 & 3.57 & 4.674 & 0.696 & 2.685 & 5.938 & 5.150 & 5.544 & 0.500 & 0.375 & 0.438 \\
\hline W3 & 26.56 & 7.66 & 17.11 & 21.44 & 5.172 & 13.31 & 13.97 & 6.625 & 10.30 & 0.763 & 0.538 & 0.650 \\
\hline A & 10.48 & 8.46 & 9.47 & 4.446 & 4.638 & 4.542 & 6.450 & 6.788 & 6.619 & 0.550 & 0.450 & 0.500 \\
\hline Mean & 14.00 & 6.43 & 10.22 & 8.321 & 3.156 & 5.738 & 6.830 & 5.240 & 6.035 & 0.508 & 0.440 & 0.474 \\
\hline \multicolumn{13}{|l|}{$\mathrm{LSD}_{0.05}$} \\
\hline I factor & 0.16 & & & 0.922 & & & 1.495 & & & 0.149 & & \\
\hline II factor & 0.069 & & & 0.395 & & & 0.640 & & & 0.064 & & \\
\hline \multicolumn{13}{|l|}{ Interaction } \\
\hline $\mathrm{I} / \mathrm{II}$ & 0.227 & & & 1.303 & & & 2.114 & & & 0.211 & & \\
\hline II/I & 0.153 & & & 0.882 & & & 1.431 & & & 0.143 & & \\
\hline
\end{tabular}

$C$ control, $W 1, W 2, W 3$ uncontrolled landfill sites, $A$ arable field, $L S D_{0.05}$ least significant difference

demonstrate a naturally high content of humus gradually accumulating in the surface layer. The key source of organic matter in the control soil was a gradual accumulation of the matter from fallen tree leaves and dead undergrowth (Brogowski and Chojnacki 2013), while in sites $\mathrm{W} 1$ and $\mathrm{W} 2$, due to the waste deposited, there was no inflow of fresh organic matter and easily water-soluble humus compounds (fulvic acids), produced as a result of the process of mineralisation, can get leached out deep down the soil profile and accumulated in the lower layer of the parent material.

The content of organic carbon is one of the most essential soil parameters and so its deficit affects other soil properties; hence, a lower carbon content under W1 and $\mathrm{W} 2$ as well as a definitely higher value under $\mathrm{W} 3$, as an effect of the waste accumulated, must have affected other physicochemical and biological soil parameters.

The content of heavy metals $(\mathrm{Pb}, \mathrm{Ni}$ and $\mathrm{Cd})$ soluble in the mixture of concentrated acids $\mathrm{HF}$ and $\mathrm{H}_{2} \mathrm{ClO}_{4}$ in the soil surface horizons under landfill sites was as follows: for lead-3.71 to $21.44 \mathrm{mg} \mathrm{kg}^{-1}$ (CV $102 \%$ ), for nickelfrom 4.0 to $13.97 \mathrm{mg} \mathrm{kg}^{-1}$ (CV 73.1\%) and cadmiumfrom 0.4 to $0.763 \mathrm{mg} \mathrm{kg}^{-1}$ (CV $26.3 \%$ ) (Table 5). Based on the analysis of variance a significant effect of the soil sampling location was found. The highest concentration of heavy metals was noted in the soil under landfill site W3 (on average $\mathrm{Pb} 13.31 \mathrm{mg} \mathrm{kg}^{-1}$; Ni $10.3 \mathrm{mg} \mathrm{kg}^{-1}$; $\mathrm{Cd}$ $0.65 \mathrm{mg} \mathrm{kg}^{-1}$ ); those values were even several-fold higher than the ones found in the control sample and in the other sampling locations. A higher content of the heavy metal in the soil under landfill site W3, as compared with other sites, must be the effect of decomposing organic residue from waste which contributed to the accumulation of organic matter, which in turn, affected its retention in soil. Land rich in organic matter actively retains metallic elements. The concentration of metals depends on the possibility of forming, together with organic soil components, complex or chelate compounds. The stability of chelates depends on, e.g. on the soil reaction and the kind of the metal ion (Gustafsson et al. 2003; Khan et al. 2010). In the soil under landfill site $\mathrm{W} 3$, with a neutral reaction and a considerable content of humus, no migration of the metals under study occurred. The depth of the soil sampling also showed a significant effect on the content of the metals studied. The values recorded in the surface horizons exceeded the content in the subsurface horizons (Table 2). Under Regulation of Minister of Environment (2002) on the standards of soil and earth quality, all the data are characteristics for the unpolluted areas. However, according to the boundary values proposed by Kabata-Pendias et al. (1993), the soil in landfill site W3, in the samples of which a high concentration of $\mathrm{Cd}$ was noted; this was the only one which can be considered to represent soils with an elevated content of that metal $\left(\mathrm{I}^{\circ}\right.$ pollution with $\left.\mathrm{Cd}\right)$. The elevated contents of cadmium in the surface horizons of sandy soils are a result of an increased organic matter and the soil capacity for retaining heavy metals. One shall note the relationships between the occurrence of heavy metals and their bioavailability, and the physicochemical properties of soil. The mobility of heavy metals in the landfill site is determined by environmental conditions, the water content and chemical bonds, with fine-grain materials, 
precipitation in a form of salts, the precipitation with ferriferous or phosphorus minerals or bonding with the organic soil phase being most essential. The phase critical for metals mobilisation is the acid phase. An increase in redox potential and a decrease in the reaction value which occurs in the acid phase of waste deposition with a little amount of organic matter enhance the mobility of the following metals: lead, cadmium, zinc, copper and mercury (Bouzayani et al. 2014; Liu and Sang 2010). Such conditions could have occurred in sites W1 and W2 and heavy metals got leached out deep down the soil profile.

The microbiological analyses showed that depositing waste at the locations not allocated for such purpose significantly disturbed the microbiological balance. The count of the groups of microorganisms assayed in the control point was compared with the values recorded in the soil under landfill sites $\mathrm{W} 1, \mathrm{~W} 2$ and $\mathrm{W} 3$, which facilitated pointing to the places where there occurred inhibition and

(a)

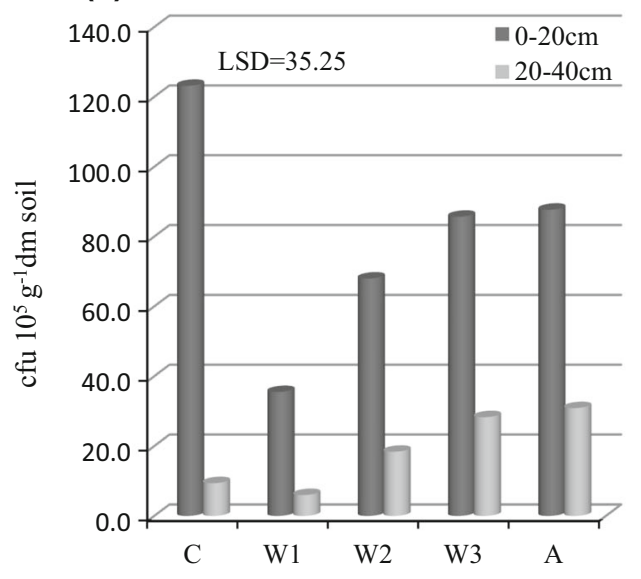

(c)

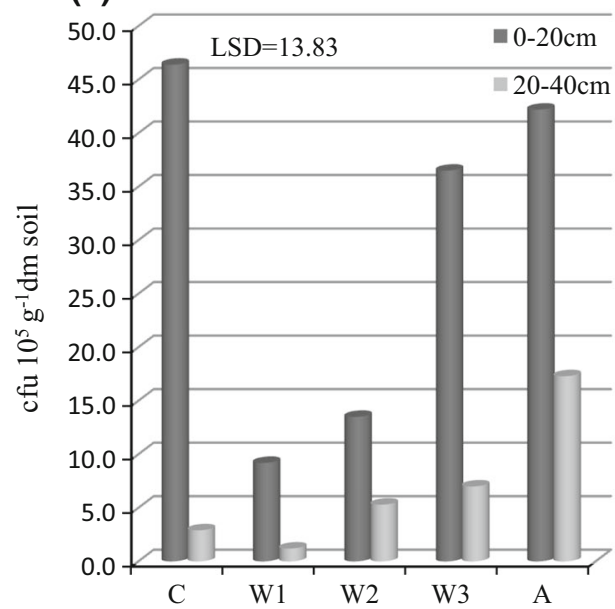

Fig. 1 Number of microorganisms in soil under uncontrolled landfill sites (W1, W2, W3), arable field (A) and point control (C); a total count of bacteria, b amylolytic microorganisms, c cellulolytic where soil microflora development got stimulated. A change in the abundance of microorganisms was determined by not only the location of the testing points but also the level of the soil sampling depth. Not all the groups of microorganisms reacted similar to the effect of the deposited waste. The highest values for the total population of bacteria were reported in the surface layer of the control point $(\mathrm{C})$ and they were significantly higher, as compared with the other testing sites (Fig. 1a). Definitely the lowest count of bacteria was determined in the soil from landfill site $\mathrm{W} 1$, followed by W2. However, in the soil sampled under the landfill site containing organic waste (W3) as well as under corn (A), similar counts of bacteria were reported, 85.7 and $87.7 \times 10^{5} \mathrm{cfu} \mathrm{g}^{-1}$ d.m. of soil, respectively. The statistical analysis confirmed that a significant factor affecting the count of bacteria was also the depth where the bacteria were isolated from. In the soil surface layer there was significantly more bacteria in total

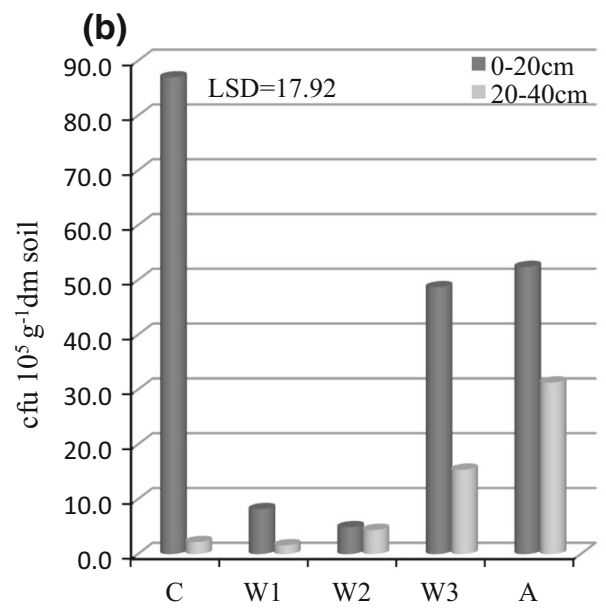

(d)

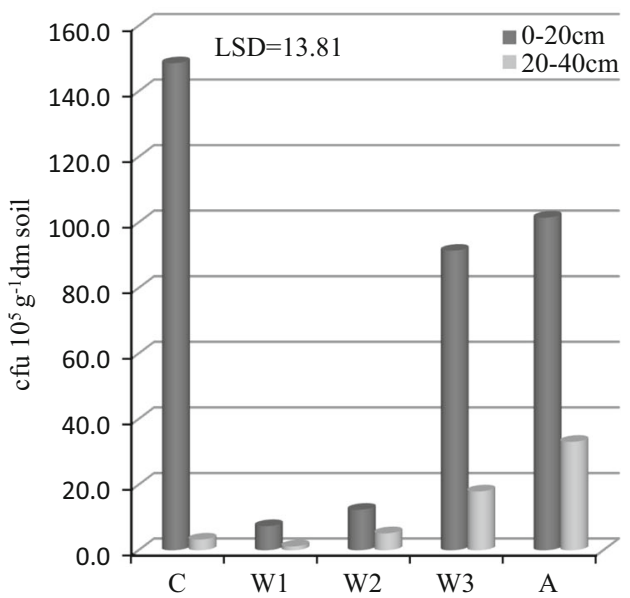

microorganisms, d proteolytic microorganisms. $\mathrm{LSD}_{0.05}$ for interaction I/II, I factor- sampling locations, II factor- depth [cm] 
Table 3 Activity of dehydrogenases (DEH) and catalase (CAT)

\begin{tabular}{|c|c|c|c|c|c|c|c|c|c|c|c|c|}
\hline \multirow{4}{*}{$\begin{array}{l}\text { Sampling location } \\
\text { I factor }\end{array}$} & \multicolumn{3}{|l|}{$\mathrm{DEH}$} & \multicolumn{3}{|l|}{ CAT } & \multicolumn{3}{|l|}{$\mathrm{DEH}$} & \multicolumn{3}{|l|}{ CAT } \\
\hline & \multicolumn{3}{|c|}{$\mathrm{mg}$ TPF kg ${ }^{-1} 24 \mathrm{~h}^{-1}$} & \multicolumn{3}{|c|}{$\mathrm{mM} \mathrm{H} \mathrm{H}_{2} \mathrm{O}_{2} \mathrm{~kg}^{-1}$ soil $\min ^{-1}$} & \multicolumn{3}{|c|}{$\mathrm{mg}$ TPF $\mathrm{kg}^{-1} \mathrm{C}_{\text {org }} 24 \mathrm{~h}^{-1}$} & \multicolumn{3}{|c|}{$\mathrm{mM} \mathrm{H}_{2} \mathrm{O}_{2} \mathrm{~kg}^{-1} \mathrm{C}_{\text {org }} \min ^{-1}$} \\
\hline & \multicolumn{12}{|c|}{ Depth $[\mathrm{cm}] \mathrm{II}$ factor } \\
\hline & $0-20$ & $20-40$ & mean & $0-20$ & $20-40$ & mean & $0-20$ & $20-40$ & mean & $0-20$ & $20-40$ & mean \\
\hline $\mathrm{C}$ & 0.132 & 0.108 & 0.120 & 18.92 & 11.38 & 15.15 & 5.652 & 8.955 & 7.303 & 810 & 944 & 877 \\
\hline W1 & 0.180 & 0.072 & 0.126 & 17.28 & 7.857 & 12.57 & 43.80 & 30.40 & 37.11 & 4206 & 3298 & 3752 \\
\hline W2 & 0.432 & 0.228 & 0.330 & 45.57 & 23.57 & 34.57 & 78.23 & 141.7 & 109.9 & 8256 & 14,569 & 11,458 \\
\hline W3 & 8.268 & 2.136 & 5.202 & 89.57 & 42.49 & 66.00 & 311.4 & 279.0 & 295.2 & 3373 & 5543 & 4458 \\
\hline A & 4.620 & 0.936 & 2.778 & 48.71 & 29.85 & 39.28 & 441.0 & 110.6 & 275.8 & 4649 & 3530 & 4090 \\
\hline Mean & 2.726 & 0.696 & 1.711 & 44.01 & 23.02 & 33.51 & 176.0 & 114.1 & 145.8 & 4249 & 5595 & 4927 \\
\hline \multicolumn{13}{|l|}{$\mathrm{LSD}_{0.05}$} \\
\hline I factor & \multicolumn{3}{|l|}{0.133} & \multicolumn{3}{|l|}{6.587} & \multicolumn{3}{|l|}{16.27} & \multicolumn{3}{|l|}{3257} \\
\hline II factor & \multicolumn{3}{|l|}{0.057} & \multicolumn{3}{|l|}{2.821} & \multicolumn{3}{|l|}{6.968} & \multicolumn{3}{|l|}{ n.s. } \\
\hline \multicolumn{13}{|l|}{ Interaction } \\
\hline $\mathrm{I} / \mathrm{II}$ & \multicolumn{3}{|l|}{0.189} & \multicolumn{3}{|l|}{9.316} & \multicolumn{3}{|l|}{23.01} & \multicolumn{3}{|l|}{4606} \\
\hline $\mathrm{II} / \mathrm{I}$ & \multicolumn{3}{|l|}{0.128} & \multicolumn{3}{|l|}{6.307} & \multicolumn{3}{|l|}{15.58} & \multicolumn{3}{|l|}{3118} \\
\hline
\end{tabular}

$C$ control, W1, W2, W3 uncontrolled landfill sites, $A$ arable field, $L S D_{0.05}$ least significant difference, n.s. differences not significant

than at the depth of $20-40 \mathrm{~cm}$, irrespective of the site. The greatest a-dozen-or-so differences in the count of the bacteria isolated were visible between horizons at point $\mathrm{C}$ (Table 3).

Exactly the same tendencies, as those noted in the occurrence of the total population of bacteria in the objects monitored, were reported still for three physiological groups of microorganisms (Fig. 1b-d). Amylolytic (Fig. 1b), cellulolytic (Fig. 1c) and proteolytic microorganisms (Fig. 1d) were isolated mostly in the surface layer of forest soil (C) and definitely least from the area of landfill sites W1 and W2. The count of microorganisms hydrolysing starch and protein in soil under W3 and arable field was also significantly lower, as compared with the control and, at the same time, from a few to a dozen-or-so times higher than in the soil under landfill site W1 and W2. As for the total count of bacteria and for those three groups, the vertical distribution in soil was similar. In the layer at the depth of 20-40 cm the lowest count of microorganisms hydrolysing starch, cellulose and protein occurred under landfill site $\mathrm{W} 1$ and the control, while most in the arable soil (point A). The research performed by Furczak and Joniec (2002) on the activity of proteases in the 0-20 and $20-40 \mathrm{~cm}$ soil layers points to their clear stimulation in the upper soil layer; however, this effect depended on the supply of the content of the fertilisation material.

The analysis of the correlation shows a significant relationship between the content of $\mathrm{C}_{\text {org }}$ and the total count of bacteria, amylolytic, cellulolytic and proteolytic microorganisms (Table 4). Similarly, according to Taylor et al. (2002), the enzymatic activity of microorganisms correlates with the content of $\mathrm{C}_{\text {org }}$. The studies defining the count of active proteolytic, cellulolytic, amylolytic microorganisms can provide much precious information on the state of the soil environment. The level of the count of physiological groups of microorganisms points to the intensity of the catalysed transformations, e.g. the decomposition of protein, cellulose and starch. Their lowered amount in soil can indicate that, in that environment various inhibitors exist (Schloter et al. 2003). Such phenomenon could be seen in the soil surface layer from the area of dumping sites W1 and W2 since the count of cellulolytic, amylolytic and proteolytic microorganisms was many-fold lower than in the control and in the arable soil.

Different relationships were found for the occurrence of Actinobacteria (Fig. 2a). Exceptionally low counts were isolated from the control soil (C) since they did not exceed $1.8 \times 10^{4} \mathrm{cfu} \mathrm{g}^{-1}$ d.m. of soil. Definitely more Actinobacteria occurred in the other measurement points and the highest count $\left(235.5 \times 10^{4} \mathrm{cfu}\right)$ was reported in landfill site W3. Similarly in the soil under corn (point A) there occurred significantly more Actinomycetes than in points W1, W2 and C. The count of Actinobacteria was also affected by the soil sampling depth. The greatest disproportions in the count of Actinobacteria across the horizons occurred in the soil under landfill site W3 and arable land, as much as fivefold, and much lower in the control soil and from objects $\mathrm{W} 1$ and W2. A significant correlation was found between the count of Actinobacteria and $\mathrm{pH}$ value. The development of Actinobacteria was most stimulated by the soil conditions within landfill site W3 where, at the same time, the highest content of carbon $\left(26.56 \mathrm{~g} \mathrm{~kg}^{-1}\right)$ 
Table 4 Correlation coefficients among the investigated parameters

\begin{tabular}{|c|c|c|c|c|c|c|c|c|c|c|c|c|c|}
\hline & B.total & Actin. & Amyl. & Cel. & Prot. & $\mathrm{DEH}$ & CAT & $\mathrm{C}_{\text {org }}$ & $\mathrm{H}_{2} \mathrm{O}$ & $\mathrm{KCl}$ & $\mathrm{Pb}$ & $\mathrm{Ni}$ & $\mathrm{Cd}$ \\
\hline B. total & - & & 0.88 & 0.941 & 0.916 & & & 0.727 & & & & & \\
\hline Actin. & & - & & & & 0.990 & 0.921 & & 0.691 & 0.667 & 0.861 & 0.947 & 0.912 \\
\hline Amyl. & & & - & 0.948 & 0.985 & & & 0.790 & & & & & \\
\hline Cel. & & & & - & 0.973 & & & 0.765 & & & & & \\
\hline Prot. & & & & & - & & & 0.805 & & & & & \\
\hline DEH & & & & & & - & 0.914 & & 0.748 & 0.720 & 0.829 & 0.908 & 0.917 \\
\hline CAT & & & & & & & - & & 0.697 & 0.703 & 0.822 & 0.911 & 0.926 \\
\hline $\mathrm{C}_{\text {org }}$ & & & & & & & & - & & & 0.849 & & \\
\hline $\mathrm{H}_{2} \mathrm{O}$ & & & & & & & & & - & & & 0.670 & 0.801 \\
\hline $\mathrm{KCl}$ & & & & & & & & & & - & & 0.646 & 0.800 \\
\hline
\end{tabular}

B. total total count of bacteria, Actin. Actinobacteria, Amyl. amylolytic microorganisms, Cel cellulolytic microorganisms, Prot proteolytic microorganisms, $D E H$ dehydrogenases, $C A T$ catalase

Fig. 2 Number of microorganisms in soil under uncontrolled landfill sites (W1, W2, W3), arable field (A) and point control $(\mathrm{C})$; a actinobacteria, b fungi. $\mathrm{LSD}_{0.05}$ for interaction I/II (a)

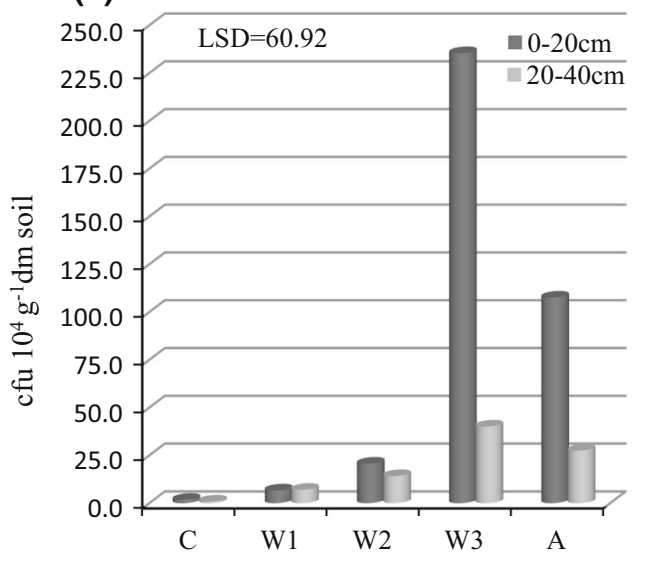

(b)

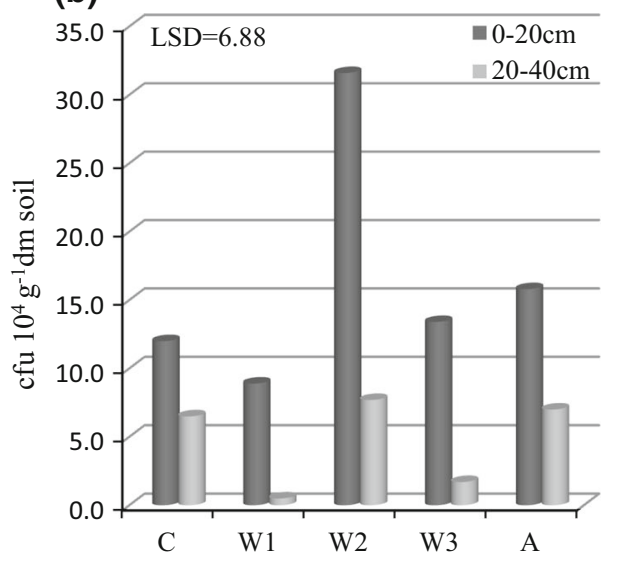

and $\mathrm{pH}$ (7.17) was noted. The effect of bio-degrading organic waste in landfill W3 was an increase in the amount of $\mathrm{C}$ org in soil, which, in turn, mostly contributed to the increase in the count of Actinobacteria. They are typical soil microorganisms and they always occur where organic matter is found at large amounts. A high enzymatic activity provides them with a high potential of decomposing various substances; simple carbohydrates and polysaccharides, hydrocarbons, steroids, lignins, chitin and humic acids (Romani et al. 2006). Microorganisms representing the order Actinomycetes are in general, aerobic organisms, although one can find a few anaerobic species representing the genera Actinomycetes and Micromonospora (Eppard et al. 1996), and it is obvious that their count in soil decreases with depth (Taylor et al. 2002). One can assume that an increased development of Actinobacteria in soil in landfill site W3, as compared with fungi, which were here isolated at much lower numbers, comes from the fact that Actinobacteria got most adapted to the conditions changed due to the waste accumulated there. Actinobacteria are known from the decomposition of hardly biodegradable substances and their use as the source of carbon, with which, on the other hand, other groups of microorganisms cannot cope. According to Fraczek and Ropek (2011), the count of Actinobacteria as well as other groups of microorganisms in the soil of arable fields in the neighbourhood of landfill sites depends on the distance and the geographic direction of the location of the land under use against the landfill site. In their studies they reported definitely least Actinobacteria in the soil from remedied sector of the landfill site of municipal solid waste.

As affected by various substances reaching the soil with pollutions, the qualitative composition of microbicenoses gets modified; there is a recession of many genera of bacteria which, so far, dominated the group of autochtonic microflora, the advantage is taken over by other species, mostly fungi representing the class of Deuteromycetes (Romaní et al. 2006). Hyphae fungi were determined in biggest numbers in the soil in landfill site W2 (Fig. 2b). In all the other points their number was significantly lower. 
The conditions least favourable for the development of fungi occurred in the soil under W1 since their number in the $0-20 \mathrm{~cm}$ layer was $8.9 \times 10^{4} \mathrm{cfu}$ and in the $20-40 \mathrm{~cm}$ layer- $0.5 \times 10^{4} \mathrm{cfu} \mathrm{g}^{-1} \mathrm{~d} . \mathrm{m}$. of soil. The comparison of fungi with other isolated groups of microorganisms shows that it was not too high since it did not exceed $31.6 \times 10^{4} \mathrm{cfu} \mathrm{g}^{-1} \mathrm{~d} . \mathrm{m}$. of soil. As already highlighted, an important factor affecting the development of assemblages of soil microorganisms is $\mathrm{pH}$. Hyphae fungi, as compared with bacteria or Actinobacteria, are more tolerant to a lowered reaction of the environment. Acid reaction does not show an inhibiting effect on the development of fungi, which accounts for the occurrence of their greatest amounts in soil with the lowest $\mathrm{pH}$ of 4.42 . During their development, moulds form an abundant branched out mycelium, which loosens the soil structure and enhances the permeability of processed waste and, at the same time, has a favourable effect on improving aerobic conditions of the environment (Sinegani et al. 2005). The soil sampling depth for the purpose of analyses was also of significant importance for the number of fungi. Both in the area of landfill sites and outside their effect there were more fungi in the $0-20 \mathrm{~cm}$ than in the $20-40 \mathrm{~cm}$ layer. Similarly Taylor et al. (2002) and Fierer et al. (2003) showed the greatest number of fungi and other microorganisms in the surface soil layer, which was decreasing deep down the soil profile.

The research shows that uncontrolled landfill sites affected the microbiological composition of soil. The waste accumulated in W1 and W2 led to the soil depletion in organic matter, which in turn, inhibited the development of microorganisms and their enzymatic activity. A definitely lower content of $\mathrm{C}_{\text {org }}$ in soil under $\mathrm{W} 1$ and $\mathrm{W} 2$, as compared with the control (for similar $\mathrm{pH}$ ) limited the availability of that element to heterotrophic microorganisms, which, as a result, decreased their count. The statistical analysis revealed a significant effect of the testing site on the count of the groups of microorganisms studied. The comparison of the count of microorganisms identifies that all the groups were most unfavourably affected by the waste deposited in landfill site W1. At that place the count of microorganisms isolated from both depths was lowest and the numerical values were from a few-to-a-few dozen times lower, as compared with the other sites $(\mathrm{C}, \mathrm{A}, \mathrm{W} 3$ and W2). The waste accumulated, especially the toxic compounds they contain, can undergo many chemical and biochemical transformations, migrate deep down the soil and get included into geochemical cycles (Halasz et al. 2008). The highest concentration of heavy metals was assayed in the soil under landfill site W3, whereas in the soil under W1 and W2, it was a few-fold lower. Irrespectively, the level of the count of microorganisms (except for fungi) was definitely higher in soil W3 than in W1 and W2. Only a higher content of $\mathrm{Ni}$ and $\mathrm{Cd}$ was noted in the soil samples under W1 and W2, as compared with the control. The lack of a negative effect of heavy metals on microorganisms in the soil under landfill site W3 could have been due to other factors. Drawing on the vast collection of literature, one shall state that the bioavailability of heavy metals in soil is affected by many parameters (granulometric composition, organic matter content, occurrence and form of cations, $\mathrm{pH}$ value, sorption capacity, content of macro and micronutrients, oxidationreduction potential) (Frey et al. 2006; Liu and Sang 2010; Oliveira and Pampulha 2006). Increasing the amount of organic matter in the soil under W3, helps to minimise the absorption of heavy metals by microorganisms The formation of metal-organic complexes in soil is very important due to the prevention of leaching of toxic ions of heavy metals from soil, as well as their partial detoxication and limiting the uptake by microorganisms (Gustafsson et al. 2003; Khan et al. 2010). The reports by Frey et al. (2006) show that the greater the pollution of forest soils with waste containing heavy metals, the greater the count of Actinobacteria, while the ratio of the count of bacteria to the count of Actinobacteria decreases, as Actinobacteria show a high activity in the decomposition of organic matter (Romaní et al. 2006). Thanks to all that the harmful effect of heavy metals can be, to some extent, eliminated. The results reveal that the statistical analysis points to a positive correlation between the count of Actinobacteria and the heavy metals studied, including the highest value reported for nickel; $\mathrm{Ni}(r=0.947, p<0.05), \mathrm{Pb} \quad(r=0.861$, $p<0.05), \mathrm{Cd}(r=0.912, p<0.05)$ (Table 4$)$.

The count of microorganisms demonstrates a very high results variation, which was confirmed with an extremely high value of the coefficient of variation (CV 80.0-159\%) (Table 5). The highest disproportions between landfill sites $\mathrm{W} 1$ and $\mathrm{W} 2$ and the control site were reported in the total count of bacteria, amylolytic, cellulolytic, proteolytic

Table 5 Statistical parameters of the content of the microbes, activity enzymes and the organic carbon and heavy metals

\begin{tabular}{|c|c|c|c|c|c|c|c|c|c|c|c|c|}
\hline Parameters & B.total & Actin. & Amyl. & Cel. & Prot. & Fungi & DEH & CAT & $\mathrm{C}_{\text {org }}$ & $\mathrm{Pb}$ & $\mathrm{Ni}$ & $\mathrm{Cd}$ \\
\hline SD & 39.4 & 73.6 & 28.8 & 17.1 & 52.3 & 8.80 & 2.71 & 24.3 & 8.48 & 5.89 & 4.85 & 0.12 \\
\hline $\mathrm{CV}[\%]$ & 80.0 & 159 & 112 & 94.1 & 123 & 83.9 & 158 & 72.6 & 83.03 & 102 & 73.1 & 26.3 \\
\hline
\end{tabular}

B. total total count of bacteria, Actin. Actinobacteria, Amyl. amylolytic microorganisms, Cel cellulolytic microorganisms, Prot proteolytic microorganisms, $D E H$ dehydrogenases, $C A T$ catalase; $S D$ standard deviation, $C V$ coefficient of variation 
microorganisms, and the lowest-in the count of fungi, which can point to disturbed biological balance in the soil environment and unfavourable changes in the microbiocenotic composition as well as soil metabolism. The reports by Bielińska and Mocek-Płóciniak (2009) confirm high differences in the biological soil activity in the area and the neighbourhood of uncontrolled landfill sites as well as a varied degree of soil contamination. A considerable intensity of the occurrence of the groups of microorganisms studied and biochemical processes was observed in the soil under landfill site W3, as compared with the control, which must have been connected with the richness of organic compounds in the waste deposited which had a direct effect on the surface soil layer. The soil in landfill site W3 showed the highest values recorded for physicochemical properties, the count of Actinobacteria, as well as the enzymatic activity. Such high values were not recorded at the other sampling points, which must have been due to the type of the waste accumulated in landfill W3, the composition of which was dominated by the biodegradable waste of organic origin with a large amount of plant residue. The landfill, located $30 \mathrm{~m}$ away from the arable field, did not deteriorate its microbiological soil properties. The differences in the count of microorgnisms in soil in damping site W3 and under corn plantation were inconsiderable; Actinobacteria were the only ones proven significantly more under the waste deposited. The studies reported by Bielińska and Mocek-Płóciniak (2009) showed that the zone of the effect of uncontrolled landfills does not exceed 50-70 m. According to Natywa et al. (2010), growing corn has a negative effect on the balance of organic substance depleting soil, and that happens due to numerous tillage treatments. The results reported by those authors show that the total count of bacteria and actinomycetes in soil under corn was similar to that reported in this paper in the soil studied in the neighbourhood of landfill W3, however, Natywa et al. (2010) isolated less fungi with a maximum of $74.5 \times 10^{3} \mathrm{cfu} \mathrm{g}^{-1} \mathrm{~d}$.m. soil.

The activity of dehydrogenases and catalase provides information on the count and activity of soil microorganisms. Both redox enzymes are very sensitive to pollution with heavy metals. Their activity is used as a test of heavy metals toxicity. Based on the analysis of variance a significant effect of both the types of the waste deposited and depth on the activity of dehydrogenases in soil was found. The greatest activity of that enzyme was recorded in the soil sampled from the soil under landfill W3, where organic waste was stored $\left(5.202 \mathrm{mg}\right.$ TPF $\mathrm{kg}^{-1}$ soil $24 \mathrm{~h}^{-1}$ ) (Table 3), which was connected with the supply of organic compounds in landfills deposited into soil, which at the same time, intensifies the enzymatic activity (Fierer et al. 2003). The lowest activity of dehydrogenases was recorded in the control soil sampled, which was not affected by landfill sites $\left(0.120 \mathrm{mg}\right.$ TPF kg ${ }^{-1}$ soil $\left.24 \mathrm{~h}^{-1}\right)$. The usual decreases in the activity of that enzyme are connected with oxygen deficit in soil, inaccessibility of nutrients or $\mathrm{pH}$ changes. In the soil sampled from field (A) where corn was grown for silage and which was located in the vicinity of landfill site W3 (about $30 \mathrm{~m}$ away) the activity was $2.778 \mathrm{mg}$ TPF $\mathrm{kg}^{-1}$ soil $24 \mathrm{~h}^{-1}$. The activity of dehydrogenases points to a very high results variation, which was confirmed with an extremely high value of the coefficient of variation (CV $158 \%$ ) (Table 5), which in turn, was affected by both the soil sampling place, and the depth and the type of the waste deposited.

The activity of catalase, similar to dehydrogenases, was highest in the soil sampled from point W3 (both from the depth of $0-20 \mathrm{~cm}-89.57 \mathrm{mM} \mathrm{H}_{2} \mathrm{O}_{2} \mathrm{~kg}^{-1}$ soil $\mathrm{min}^{-1}$, and from $20-40 \mathrm{~cm}-42.49 \mathrm{mM} \mathrm{H}_{2} \mathrm{O}_{2} \mathrm{~kg}^{-1}$ soil $\mathrm{min}^{-1}$ ), while the lowest activity of the enzyme was reported in the soil sampled from point $\mathrm{W} 1\left(12.57 \mathrm{mM} \mathrm{H}_{2} \mathrm{O}_{2} \mathrm{~kg}^{-1}\right.$ soil $\mathrm{min}^{-1}$, mean for both depths), which was connected with the type of waste deposited (Table 3). Catalase released from the cell also shows a considerable stability in soil - thanks to the sorption at the surface of clay minerals as well as the adsorption with soil organic colloid. Catalase is active over a wide $\mathrm{pH}$ range, and its activity does not drop until $\mathrm{pH}$ goes below 3.5. In the present research $\mathrm{pH}$ ranged as follows: $\mathrm{pH}_{\mathrm{H} 2 \mathrm{O}} 4.42-7.35$ as well as $\mathrm{pH}_{\mathrm{KCl}} 3.36-7.30$. A high value of the coefficient of variation $(\mathrm{CV}=72.6 \%)$ (Table 5) of catalase activity showed a low homogeneity of the results, with most of the results being lower than the mean value.

Both the activity of dehydrogenases and catalase was decreasing with depth (Table 3 ). The highest activity of dehydrogenases $\left(2.726 \mathrm{mg} \mathrm{TPF} \mathrm{kg}^{-1} 24 \mathrm{~h}^{-1}\right)$ and catalase (44. $\mathrm{mM} \mathrm{H}_{2} \mathrm{O}_{2} \mathrm{~kg}^{-1}$ soil $\mathrm{min}^{-1}$ ) was found in the soil sampled from horizon 0-20 $\mathrm{cm}$. In the subsurface layer the activity of dehydrogenases was $76 \%$ lower, and catalase$48 \%$ lower, which is connected with the distribution of organic matter as well as microorganisms in soil (Kizilkaya and Dengiz 2010). Deep down the soil profile there is a decrease in the count of microorganisms and the amount of humus as well as exudations from plant roots, constituting the main source of food for soil organisms (Song et al. 2008).

The analysis of correlation identified a practically complete dependence between the activity of soil dehydrogenases and the content of $\mathrm{Pb}(r=0.829, p<0.05), \mathrm{Ni}$ $(r=0.908, p<0.05)$ as well as $\mathrm{Cd}(r=0.917, p<0.05)$, which must have been a result of a lack of a negative effect of heavy metals on the activity of enzymatic proteins of microorganisms. Neither the count nor the species diversity of microorganisms being the source of soil enzymes changed. The natural content of heavy metals did not cause oxidative stress (Dong et al. 2006), and so there occurred 
no inhibition of the activity of dehydrogenases and soil catalase. Heavy metals at low concentrations can stimulate the development of microorganisms and thus the activity of enzymes in soil.

No significant dependencies were recorded between the activity of the enzymes studied and the content of organic carbon. According to Bielińska et al. (2013), it could have been due to a low share of humus substances, thus limiting the access to easily available $\mathrm{C}$ determining the development of microorganisms being the source of enzymes. Usually a low content of organic matter in soil makes it difficult to compare the absolute values of the enzymatic activity and makes a clear diagnosis of their variation impossible since it is not possible to determine whether the changes are due to a low content of organic matter or whether there is a real difference in their activity (TrasarCepeda et al. 2008). For that reason, to compare the effect of the factors studied on the enzymatic changes of soil the values of their activity per $\mathrm{C}_{\text {org }}$ are used (Barriuso et al. 1988). The lowest activity of the oxidoreductases was reported in the soil sampled from the control point ( $\mathrm{DEH}$

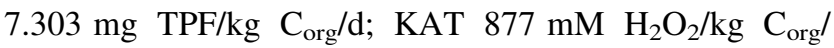
$\mathrm{min})$. In the soil covered by the impact of uncontrolled landfill sites, the highest activity of dehydrogenases was recorded in the soil from point W3 $\left(295.2 \mathrm{mg} \mathrm{TPF} / \mathrm{kg} \mathrm{C} \mathrm{C}_{\text {org }}\right.$ / d), whereas catalase $\mathrm{W} 2\left(11458 \mathrm{mM} \mathrm{H} \mathrm{H}_{2} / \mathrm{kg} \mathrm{C}_{\text {org }} / \mathrm{min}\right)$ (Table 3 ). In the soils affected by anthropogenic impact there was a significant decrease in organic matter (Table 3) and the changes also led to a relatively lower activity of the oxidoreductases expressed in $\mathrm{C}_{\text {org }}$. According to TrasarCepeda et al. (2008), greater organic matter losses in soil stimulate the enzymatic activity expressed in $\mathrm{C}_{\text {org }}$., which, however, was not confirmed by our research.

Uncontrolled waste damping in forest and mid-field areas can deteriorate biological and physicochemical soil properties, and so such places should be controlled and evaluated in terms of the level of the environmental changes.

\section{Conclusions}

Defining the biological (microbiological and biochemical) as well as physicochemical parameters in soil in the area of uncontrolled landfills provides information on the state and direction of changes in the soil environment. The waste deposited in an inadequate place disturbed the biological activity of soil. Unlimited and uncontrolled emissions of various substances into soil inhibit the development of soil bacteria and, as a result, result in a decrease in their count and enzymatic activity, which disturbs the soil environment homeostasis. The count of microorganisms in soil of the arable fields neighbouring with the landfill site did not differ considerably from the count in the soil of sustainable forest ecosystem. The greatest disproportions were seen in the count of Actinobacteria.

The composition of the waste accumulated showed to be an essential element affecting the count of microorganisms and their enzymatic activity as well as physicochemical properties. In the area of the landfill site containing mixed waste, including debris, plastics, metals, textiles and used electrotechnical equipment the lowest values of all the indices studied were noted. The conditions most stimulating for the development of microorganisms and a considerable intensity of biochemical processes as well as the highest concentration of heavy metals occurred in the soil under the landfill site containing a large amount of organic waste mostly of plant origin. One shall add, however, that the concentration of heavy metals in the soils studied, exposed to the effect of landfill sites, makes it possible to classify them as unpolluted soils with a natural content of $\mathrm{Pb}, \mathrm{Ni}, \mathrm{Cd}$.

The operating illegal places of waste deposition are a potential threat for the natural environment, which was confirmed by the present studies. Papers which cover that subject should be continued since they will allow for evaluating ecological effects of a gradual accumulation of pollution in the soils surrounding uncontrolled landfill sites of municipal solid waste.

Acknowledgments The authors would like to thank the Faculty of Agriculture and Biotechnology, University of Technology and Life Sciences, for their support for this research work.

Open Access This article is distributed under the terms of the Creative Commons Attribution 4.0 International License (http://crea tivecommons.org/licenses/by/4.0/), which permits unrestricted use, distribution, and reproduction in any medium, provided you give appropriate credit to the original author(s) and the source, provide a link to the Creative Commons license, and indicate if changes were made.

\section{References}

Atlas RM (1997) Handbook of microbiological media, 2nd edn. CRC Press, Boca Raton

Barriuso E, Pérez-Mateos M, González-Carcedo S (1988) Actividad ureásica específica del suelo. Agrochimica 32:284-294

Bielińska EJ, Mocek-Płóciniak A (2009) Impact of uncontrolled waste dumping on soil chemical and biochemical properties. Arch Environ Prot 35(3):101-107

Bielińska EJ, Kołodziej B, Sugier D (2013) Relationship between organic carbon content and the activity of selected enzymes in urban soils under different anthropogenic influence. J Geochem Explor 129:52-56. doi:10.1016/j.gexplo.2012.10.019

Boguszewska J (1980) Isolating and some properties of the extracellular amylases of Fusarium martii App. Et Wr. Var. minus f.2. Acta Mycol 26(2):237-245

Bouzayani F, Aydi A, Abichou T (2014) Soil contamination by heavy metals in landfills: measurements from an unlined leachate 
storage basin. Environ Monit Assess 186(8):5033-5040. doi:10. 1007/s10661-014-3757-y

Brogowski Z, Chojnacki J (2013) Distribution of organic matter and nitrogen in the particle size fractions of genetic horizons in Dystric Cambisols in the Kabacki Forest. Sylwan 157(6):470-480

Crock JG, Severson R (1980) Four reference soil and rock samples for measuring element availability in the western energy regions. Geochem Survey Circular 841:1-16

Dong J, Wu F, Zhang G (2006) Influence of cadmium on antioxidant capacity and four microelement concentration in tomato seedlings (Lycopersicon esculentum). Chemosphere 64:1659-1666. doi:10.1016/j.chemosphere.2006.01.030

Regulation of Minister of Environment (2002) The soil quality standards and earth quality standards Dz. U. No165, poz. 1359. http://isap.sejm.gov.pl. Accessed 9 Sept 2002

Eppard M, Krumbein WE, Koch C, Rhiel E, Staley JT, Stackebrandt E (1996) Morphological physiological, and molecular characterization of actinomycetes isolated from dry soil, rocks, and monument surfaces. Arch Microbiol 166(1):12-22. doi:10.1007/ s002030050350

Fierer N, Schimel JP, Holden P (2003) Variations in microbial community composition through two soil depth profiles. Soil Biol Biochem 35:167-176. doi:10.1016/S0038-0717(02)00251-1

Fraczek K, Ropek D (2011) Municipal waste dumps as the microbiological threat to the natural environment. Ecol Chem Eng S 18(1):93-110

Frey B, Stemmer M, Widmer F, Luster J, Sperisen C (2006) Microbial activity and community structure of a soil after heavy metal contamination in a model forest ecosystem. Soil Biol Biochem 38(7):1745-1756. doi:10.1016/j.soilbio.2005.11.032

Furczak J, Joniec J (2002) Studies upon influence of microbial and biochemical activities on a level of sludge crumbling. Pol J Soil Sci 35:59-67

Guan SP, Yu ZH, Zhong S (2014) Leak marking scheme for construction quality testing of geomembrane liners in landfills. Int J Environ Res 8(2):447-452

Gustafsson JP, Pechova P, Berggren D (2003) Modeling metal binding to soil: the role of natural organic matter. Environ Sci Technol 37(12):2767-2774. doi:10.1021/es026249t

Halasz J, Chonka I, Toth MD, Boyko N, Balazsy S (2008) Microorganism and enzyme activities in the soil of landfill sites of Bereg county. Arch Agron Soil Sci 54(5):465-479. doi:10. 1080/03650340802253911

Johnson JI, Temple KL (1964) Some variables affecting the measurements of catalase activity in soil. Soil Sci Soc Am 28:207-216

Kabata-Pendias A, Motowicka-Terelak T, Piotrowska M, Terelak H, Witek T (1993) The evaluation of the degree of soil pollution with heavy metals and sulphur Framework guidelines for agriculture. IUNG Puławy, series $\mathrm{P}(53)$ : 1-22

Khan S, Hesham AEL, Qiao M, Rehman S, He JZ (2010) Effects of $\mathrm{Cd}$ and $\mathrm{Pb}$ on soil microbial community structure and activities. Environ Sci Pollut Res Int 17(2):288-296. doi:10.1007/s11356009-0134-4

Kizilkaya R, Dengiz O (2010) Variation of land use and land cover effects on some soil physico-chemical characteristics and soil enzyme activity. Zemdirb-Agric 97(2):15-24

Liu HH, Sang SX (2010) Study on the law of heavy metal leaching in municpal solid waste landfill. Environ Monit Assess 165:349-363. doi:10.1007/s10661-009-0951-4

Martin JP (1950) Use of acid, rose bengal and streptomycin in the plate method for estimating soil fungi. Soil Sci 69:215-232

Meller E, Niedźwiecki E, Protasowicki M, Malinowski R, Sammel A, Jarnuszewski G (2012) Influence of uncontrolled dump sites on some chemical properties of organic and mineral soils developed from clay and loam in west Pomeranian. Soil Sci Ann 62(2):36-41. doi:10.2478/v10239-012-0022-3

Nagarajan R, Thirumalaisamy S, Lakshumanan E (2012) Impact of leachate on groundwater pollution due to non-engineered municipal solid waste landfill sites of erode city, Tamil Nadu, India. Iran J Environ Health Sci Eng 9(1):1-12. doi:10.1186/ 1735-2746-9-35

Natywa M, Sawicka A, Wolna-Maruwka A (2010) Microbial and enzymatic activity in the soil under maize crop in relation to differentiated nitrogen fertilization. Water Environ Rural Areas 10(2):111-120

Nwaogu LA, Ujowundu CO, Iheme CI, Ezejiofor TNI, Belonwu DC (2014) Effect of sublethal concentration of heavy metal contamination on soil physicochemical properties, catalase and dehydrogenase activities. Int $J$ Biochem Res Review 4(2):141-149. doi:10.9734/IJBCRR/2014/6341

Oliveira A, Pampulha ME (2006) Effects of long-term heavy metal contamination on soil microbial characteristics. J Biosci Bioeng 102(3):157-161. doi:10.1263/jbb.102.157

PN-ISO 10390 (1997) Chemical and agricultural analysis: determining soil $\mathrm{pH}$. Polish Standards Committee, Warsaw

PN-ISO14235 (2003) Chemical and agricultural analysis-soil quality-determining the content of organic carbon by oxidation of potassium dichromate (VI) in the environment of sulphuric acid (VI). Polish Standards Committee, Warsaw

Pochon J, Tardieux P (1962) Techniques d'analyse en microbiologie du sol Paris: Coll tech de base 111

Romaní AM, Fischer H, Mille-Lindblom C, Tranvik LJ (2006) Interactions of bacteria and fungi on decomposing litter: differential extracellular enzyme activities. Ecology 87(10): 2559-2569. doi:10.1890/0012-9658(2006)87[2559:IOBAFO]2.0. $\mathrm{CO} ; 2$

Salazar S, Sanchez L, Alvarez J, Valverde A, Galindo P, Igual J, Peix A, Santa-Regina I (2011) Correlation among soil enzyme activities under different forest system management practices. Ecol Eng 37:1123-1131. doi:10.1016/j.ecoleng.2011.02.007

Schloter M, Dilly O, Munch JC (2003) Indicators for evaluating soil quality. Agric Ecosyst Environ 98:255-262. doi:10.1016/S01678809(03)00085-9

Sinegani AAS, Emtiazi G, Hajrasuliha S, Shariatmadari H (2005) Biodegradation of some agricultural residues by fungi in agitated submerged cultures. Afr J Biotechnol 4(10):1058-1061. doi:10. 5897/AJB2005.000-3210

Song Y, Deng SP, Acosta-Martinez V, Katsalirou E (2008) Characterization of redox-related soil microbial communities along a river floodplain continuum by fatty acid methyl ester (FAME) and 16S rRNA genes. Appl Soil Ecol 40:499-509. doi:10.1016/j. apsoil.2008.07.005

Strzelczyk E, Szpotański T (1989) Cellulolytic and pectolytic actyvity of streptomycetes isolated from root-free soil, rhizosphere and mycorrhizosphere of pine (Pinus sylvestris L.). Biol Fertil Soils 7:365-369. doi:10.1007/BF00257834

Taylor JP, Wilson B, Mills MS, Burns RG (2002) Comparison of microbial numbers and enzymatic activities in surface soils and subsoils using various techniques. Soil Biol Biochem 34(3):387-401. doi:10.1016/S0038-0717(01)00199-7

Thalmann A (1968) Zur methodic derestimung der Dehydrogenaseaktivität i Boden mittels Triphenyltetrazoliumchlorid (TTC). Landwirtsch Forsch 21:249-258

Tonon G, Sohi S, Francioso O, Ferrari E, Montecchio D, Gioacchini P, Ciavatta C, Panzacchi P, Powlson D (2010) Effect of soil pH on the chemical composition of organic matter in physically separated soil fractions in two broadleaf woodland sites at Rothamsted, UK. Eur J Soil Sci 61(6):970-979. doi:10.1111/j. 1365-2389.2010.01310.x 
Trasar-Cepeda C, Leirós MC, Gil-Sotres F (2008) Hydrolytic enzyme activities in agricultural and forest soils. Some implications for their use as indicators of soil quality. Soil Biol Biochem 40:2146-2155. doi:10.1016/j.soilbio.2008.03.015
Wang YF, Tang CX, Wu JJ, Liu XM, Xu JM (2013) Impact of organic matter addition on $\mathrm{pH}$ change of paddy soils. J Soil Sediment 13:12-23. doi:10.1007/s11368-012-0578-x 